\title{
RELATIONSHIPS BETWEEN PHOSPHATASE ACTIVITY AND OTHER CHARACTERISTICS IN BULL SEMEN
}

\author{
J. D. ROUSSEL* AND O. T. STALLGUP \\ Department of Animal Industry and Veterinary Science, \\ University of Arkansas, Fayetteville, Arkansas, U.S.A.
}

(Received 6th March 1965, revised 18th March 1966)

\begin{abstract}
Summary. Alkaline and acid phosphatase levels, and various other semen characteristics, have been examined in 149 semen samples from twelve Holstein-Friesian bulls. Alkaline phosphatase and acid phosphatase mean values were $26 \cdot 1 \pm 18 \cdot 0$ and $7 \cdot 4 \pm 7 \cdot 8$ Sigma units $/ \mathrm{ml}$ for spermatozoa free of seminal plasma and $105 \cdot 7 \pm 42 \cdot 5$ and $24 \cdot 7 \pm 11 \cdot 8$ Sigma units/ml for seminal plasma. Alkaline phosphatase activity of spermatozoa was significantly correlated with the percentage of motile spermatozoa, and percentage of live spermatozoa. When acid phosphatase values were adjusted for concentration of spermatozoa per sample, highly significant negative correlations were obtained with the percentage of motile spermatozoa and the percentage of live spermatozoa, and a positive correlation with the percentage of abnormal spermatozoa. When alkaline phosphatase of seminal plasma and the alkaline phosphatase/ acid phosphatase ratio in seminal plasma were adjusted for concentration of spermatozoa per sample, highly significant negative correlations were obtained with the percentage of motile spermatozoa and the percentage of live spermatozoa, and a positive correlation with the percentage of abnormal spermatozoa. The percentage of motile spermatozoa was significantly correlated with alkaline phosphatase and acid phosphatase in seminal plasma, whereas the percentage of abnormal spermatozoa was negatively correlated with alkaline phosphatase and acid phosphatase.
\end{abstract}

\section{INTRODUCTION}

Semen owes its considerable amount of phosphatase activity mainly to the seminal plasma which abounds in different dephosphorylating enzymes derived from the male accessory organs of reproduction. Among the most active and best known enzymes in this group are the so-called acid and alkaline phosphatases (Mann, 1964).

The presence of phosphatase in bovine semen was first demonstrated by Mann (1945) and confirmed by Reid, Ward \& Salsbury (1948) and Haq \& Mullen (1949). King \& Delory (1945) and Engberg, Anderson, Sury \& Raft (1947) demonstrated that the activity of acid phosphatase in man is influenced

\footnotetext{
* Present address: Delta Regional Primate Research Center, Covington, Louisiana, U.S.A.
} 
by androgens and Reid et al. (1948) reported that phosphatase activity may be influenced by feeding, by testicular degeneration and by testicular hypoplasia. In a recent study, Bell \& Lake (1962) found that seminal acid phosphatase activity at $\mathrm{pH} 4.9$ was higher in man, the cock and turkey tom than in the boar and rabbit, with the bull intermediate, whereas alkaline phosphatase activity was highest in the boar and rabbit, lowest in the cock, turkey tom and man, with the bull again intermediate. Lundquist (1946) found very small quantities of acid phosphatase in semen of the bull.

In the present paper, the enzymatic activities of alkaline phosphatase and acid phosphatase in seminal plasma and spermatozoa free of seminal plasma from Holstein-Friesian bulls have been investigated and correlated with various other semen characteristics. This study was undertaken in order to elucidate further the significance of alkaline and acid phosphatase in semen physiology.

\section{MATERIALS AND METHODS}

An artificial vagina was used to obtain semen samples from twelve healthy Holstein-Friesian bulls ranging in age from 16 to 22 months. Two ejaculates were taken from each bull once a week, with intervals of 5 min between collections. Immediately after collection, the semen samples were stoppered and placed in a water-bath at $27^{\circ} \mathrm{C}$ and thereafter placed in a styrofoam carrier maintained at $5^{\circ} \mathrm{C}$ to prevent temperature shock and to eliminate any influence of temperature on phosphatase activity. A total of 149 semen samples was selected at random and used in this study.

The time interval between the collection and the examination of the semen characteristics was not more than $1 \frac{1}{2} \mathrm{hr}$. The collection tubes were graduated in $\mathrm{ml}$ and semen volume was measured directly. Semen samples were examined under a magnification of 440 , and the percentage of spermatozoa showing progressive forward movement was assessed in increments of $5 \%$. The percentage of morphologically abnormal spermatozoa and the percentage of live spermatozoa were determined on samples stained according to the procedure outlined by Herman \& Madden (1963). The concentration of spermatozoa was determined photometrically as outlined by Willet \& Buckner (1951).

Immediately after these semen characteristics had been determined, a portion of the semen was transferred by means of a blood volume pipette into Wintrobe tubes and centrifuged at $2000 \mathrm{~g}$ for $15 \mathrm{~min}$ in a refrigerated centrifuge at $5^{\circ} \mathrm{C}$. After centrifugation, the seminal plasma was removed from the Wintrobe tube by means of a blood volume pipette and assayed for phosphatase activity. A volume of $0.075 \mathrm{~m}$ phosphate buffer, $\mathrm{pH} 6.8$ (Sigma Stock No. 105-9), equal to that of the removed seminal plasma, was added to the spermatozoa. The suspension of buffer and spermatozoa was then assayed for phosphatase activity. Since time did not permit the assay of these samples on the day of collection, samples were stored in a refrigerator at $5^{\circ} \mathrm{C}$ for a period of $18 \mathrm{hr}$ before being assayed. Phosphatase was assayed by the method outlined by Sigma Technical Bulletin 104 (Sigma Chemical Company, 1963) and activity expressed as Sigma units/ml. One Sigma unit of phosphatase liberates $1 \mu \mathrm{M}$ of $p$-Nitrophenol $/ \mathrm{hr}(1 \mu \mathrm{M}=0 \cdot 1391 \mathrm{mg})$. Acid phosphatase was assayed at 
$\mathrm{pH} 4.8$ and alkaline phosphatase at $\mathrm{pH} 10.5$, at $38^{\circ} \mathrm{C}$. It has been reported that alkaline phosphatase activity is stable, or possibly increases by 5 to $10 \%$ after 24-hr storage in a refrigerator (Sigma Technical Bulletin 104). Acid phosphatase is not as stable as alkaline phosphatase under the prevailing conditions and the acid phosphatase values reported herein are $25 \pm 5 \%$ lower than for samples assayed immediately after collection. No attempt was made to adjust the acid phosphatase values for changes during storage of samples.

Statistical analysis of the data was in accordance with the procedures outlined by Snedecor (1956). Before analysis, the percentages of motile, live and abnormal spermatozoa were transformed to arcsins.

TABLE 1

MEANS AND STANDARD DEVIATIONS OF PHOSPHATASE ACTIVITY AND OTHER SEMEN GHARAGTERISTICS

\begin{tabular}{|c|c|c|}
\hline & Mean & $\begin{array}{l}\text { Standard } \\
\text { deviation }\end{array}$ \\
\hline $\begin{array}{l}\text { Semen characteristics } \\
\text { Volume (ml) } \\
\text { Motile spermatozoa (\%) } \\
\text { Concentration of spermatozoa }\left(\times 10^{6} \text { cells } / \mathrm{ml}\right) \\
\text { Live spermatozoa }(\%) \\
\text { Abnormal spermatozoa }(\%)\end{array}$ & $\begin{array}{c}3 \cdot 7 \\
34 \cdot 7 \\
667 \cdot 86 \\
52 \cdot 2 \\
12 \cdot 3\end{array}$ & $\begin{array}{c}1 \cdot 2 \\
4 \cdot 1 \\
340 \cdot 50 \\
3 \cdot 4 \\
2 \cdot 3\end{array}$ \\
\hline $\begin{array}{l}\text { Spermatozoa free of seminal plasma } \\
\text { Alkaline phosphatase (Sigma units } / \mathrm{ml} \text { ) } \\
\text { Acid phosphatase (Sigma units/ml) } \\
\text { Alkaline/acid phosphatase (ratio) } \\
\text { Alkaline phosphatase (Sigma units } / 500 \times 10^{6} \text { cells) } \\
\text { Acid phosphatase (Sigma units } / 500 \times 10^{6} \text { cells) } \\
\text { Alkaline/acid phosphatase } / 500 \times 10^{6} \text { cells (ratio) }\end{array}$ & $\begin{array}{r}26 \cdot 1 \\
7 \cdot 4 \\
4 \cdot 2 \\
22 \cdot 1 \\
6 \cdot 5 \\
3 \cdot 7\end{array}$ & $\begin{array}{r}18 \cdot 0 \\
7 \cdot 8 \\
3 \cdot 6 \\
16 \cdot 5 \\
6 \cdot 5 \\
2 \cdot 8\end{array}$ \\
\hline $\begin{array}{l}\text { Seminal plasma } \\
\text { Alkaline phosphatase (Sigma units/ml) } \\
\text { Acid phosphatase (Sigma units/ml) } \\
\text { Alkaline/acid phosphatase (ratio) }\end{array}$ & $\begin{array}{r}105 \cdot 7 \\
24 \cdot 7 \\
5 \cdot 2\end{array}$ & $\begin{array}{r}42 \cdot 5 \\
11 \cdot 8 \\
3 \cdot 9\end{array}$ \\
\hline $\begin{array}{l}\text { Alkaline phosphatase (Sigma units } / 500 \times 10^{6} \text { cells) } \\
\text { Acid phosphatase (Sigma units } / 500 \times 10^{6} \text { cells) } \\
\text { Alkaline/acid phosphatase } / 500 \times 10^{6} \text { cells }(\text { ratio })\end{array}$ & $\begin{array}{r}126 \cdot 34 \\
43 \cdot 02 \\
8 \cdot 50\end{array}$ & $\begin{array}{l}77 \cdot 11 \\
70 \cdot 94 \\
14 \cdot 34\end{array}$ \\
\hline
\end{tabular}

Mean data for 149 semen samples from twelve bulls.

\section{RESULTS}

The means and standard deviations of the alkaline and acid phosphatase activities found in spermatozoa and seminal plasma, and of other semen characteristics are shown in Table 1. These data were obtained from 149 semen samples collected at random from twelve healthy Holstein-Friesian bulls. The alkaline phosphatase activity was found to be four times higher in seminal plasma than in spermatozoa. A similar relationship was also observed in the activity of acid phosphatase.

The correlations of volume of semen, percentage of motile spermatozoa, concentration of spermatozoa, percentage of live spermatozoa, and percentage of morphologically abnormal spermatozoa with alkaline phosphatase and acid 
phosphatase activity of spermatozoa free of seminal plasma are shown in Table 2. Correlations with the ratio of alkaline phosphatase/acid phosphatase, and with measures of phosphatase adjusted to a common basis of cell number $\left(500 \times 10^{6}\right.$ cells), are also shown. No significant correlations were observed between volume of semen and any of the measures of phosphatase activity. The percentage of motile spermatozoa was positively correlated with alkaline phosphatase $(P<0.05)$ and with the ratio of alkaline phosphatase/acid phosphatase $(P<0.01)$, and negatively correlated with acid phosphatase when adjusted for cell number $(P<0.01)$. Highly significant $(P<0.01)$ negative correlations were

\section{TABLE 2}

CORRELATIONS BETWEEN PHOSPHATASE ACTIVITY OF SPERMATOZOA FREE OF SEMINAL PLASMA AND OTHER SEMEN GHARACTERISTICS

\begin{tabular}{|c|c|c|c|c|c|c|}
\hline & & Volume & $\begin{array}{c}\text { Percentage } \\
\text { motile } \\
\text { spermatozoa }\end{array}$ & $\begin{array}{c}\text { Concentration } \\
\text { of } \\
\text { spermatozoa }\end{array}$ & $\begin{array}{l}\text { Percentage } \\
\quad \text { live } \\
\text { spermatozoa }\end{array}$ & $\begin{array}{l}\text { Percentage } \\
\text { abnormal } \\
\text { spermatozoa }\end{array}$ \\
\hline Alkaline phosphatase/ml & $\begin{array}{l}r \\
b\end{array}$ & $\begin{array}{r}0 \cdot 08 \\
11 \cdot 62\end{array}$ & $\begin{array}{l}0.18^{*} \\
0.32\end{array}$ & $\begin{array}{l}0 \cdot 12 \\
0 \cdot 62\end{array}$ & $\begin{array}{l}0 \cdot 18 * \\
0 \cdot 28\end{array}$ & $\begin{array}{l}-0.03 \\
-0.06\end{array}$ \\
\hline Acid phosphatase/ml & $\begin{array}{l}r \\
b\end{array}$ & $\begin{array}{l}0.07 \\
3.96\end{array}$ & $\begin{array}{l}0.08 \\
0.06\end{array}$ & $\begin{array}{l}0 \cdot 15 \\
0 \cdot 34\end{array}$ & $\begin{array}{l}0.11 \\
0.08\end{array}$ & $\begin{array}{l}-0.06 \\
-0.06\end{array}$ \\
\hline Alkaline/acid phosphatase (ratio) & $\begin{array}{l}r \\
b\end{array}$ & $\begin{array}{l}0 \cdot 10 \\
2 \cdot 67\end{array}$ & $\begin{array}{l}0.22 * * \\
0.07\end{array}$ & $\begin{array}{l}0 \cdot 04 \\
0 \cdot 00\end{array}$ & $\begin{array}{l}0 \cdot 17^{*} \\
0 \cdot 05\end{array}$ & $\begin{array}{l}-0.07 \\
-0.03\end{array}$ \\
\hline Alkaline phosphatase $/ 500 \times 10^{6}$ cells & $\begin{array}{l}r \\
b\end{array}$ & $\begin{array}{l}0 \cdot 08 \\
9 \cdot 62\end{array}$ & $\begin{array}{l}0.05 \\
0.03\end{array}$ & $\begin{array}{l}-0 \cdot 38 * * \\
-1 \cdot 84\end{array}$ & $\begin{array}{l}-0.04 \\
-0.06\end{array}$ & $\begin{array}{l}0.12 \\
0 \cdot 25\end{array}$ \\
\hline Acid phosphatase $/ 500 \times 10^{6}$ cells & $\begin{array}{l}r \\
b\end{array}$ & $\begin{array}{l}-0.08 \\
-3.97\end{array}$ & $\begin{array}{l}-0.39 * * \\
-0.25\end{array}$ & $\begin{array}{l}-0.40 * * \\
-0.75\end{array}$ & $\begin{array}{l}-0.37 * * \\
-0.21\end{array}$ & $\begin{array}{l}0 \cdot 39 * * \\
0 \cdot 31\end{array}$ \\
\hline $\begin{array}{l}\text { Alkaline/acid phosphatase } / 500 \times 10^{6} \\
\text { cells (ratio) }\end{array}$ & $\begin{array}{l}r \\
b\end{array}$ & $\begin{array}{r}0 \cdot 08 \\
17 \cdot 40\end{array}$ & $\begin{array}{l}0 \cdot 12 \\
0 \cdot 32\end{array}$ & $\begin{array}{l}0 \cdot 29 * * \\
-2 \cdot 38\end{array}$ & $\begin{array}{l}0.11 \\
0.29\end{array}$ & $\begin{array}{l}-0.02 \\
-0.06\end{array}$ \\
\hline
\end{tabular}

$r$, Simple correlation coefficient; $b$, simple regression coefficient.

$$
* P<0.05 \text {; ** } P<0.01 \text {. }
$$

attained between concentrations of spermatozoa and the adjusted alkaline phosphatase, and the adjusted acid phosphatase, and a positive correlation with the ratio of alkaline phosphatase/acid phosphatase. Alkaline phosphatase and the ratio of alkaline phosphatase/acid phosphatase were significantly $(P<0.05)$ positively correlated with the percentage of live spermatozoa, whereas adjusted acid phosphatase was negatively correlated $(P<0.01)$ with the percentage of live spermatozoa. On the other hand, the percentage of abnormal spermatozoa was positively correlated $(P<0.01)$ with the adjusted acid phosphatase activity.

Correlations between the phosphatase activity of seminal plasma and other semen characteristics are presented in Table 3. Alkaline phosphatase of seminal plasma was positively and significantly $(P<0.05)$ correlated with the percentage of motile spermatozoa and negatively correlated with the percentage of abnormal spermatozoa. Acid phosphatase activity in seminal plasma was negatively correlated with volume of semen and with the percentage of morphologically abnormal spermatozoa, and positively correlated with the percentage of motile spermatozoa and with concentration of spermatozoa. All semen characteristics 
investigated were significantly correlated with the ratio of alkaline phosphatase/ acid phosphatase.

When alkaline phosphatase activity in seminal plasma was adjusted for concentration of spermatozoa, highly significant $(P<0.01)$ negative correlations were observed with the percentage of motile spermatozoa, concentration of spermatozoa, and the percentage of live spermatozoa, and a positive correlation with the percentage of morphologically abnormal spermatozoa. No significant correlations were obtained between any of the semen characteristics investigated and the adjusted acid phosphatase activity in the seminal plasma. When the alkaline phosphatase/acid phosphatase ratio was adjusted for con-

TABLE 3

CORRELATIONS BETWEEN SEMINAL PLASMA PHOSPHATASE ACTIVITY AND OTHER SEMEN GHARACTERISTICS

\begin{tabular}{|c|c|c|c|c|c|c|}
\hline & & Volume & $\begin{array}{l}\text { Percentage } \\
\text { motile } \\
\text { spermatozoa }\end{array}$ & $\begin{array}{l}\text { Concen- } \\
\text { tration of } \\
\text { spermatozoa }\end{array}$ & $\begin{array}{l}\text { Percentage } \\
\quad \text { live } \\
\text { spermatozoa }\end{array}$ & $\begin{array}{l}\text { Percentage } \\
\text { abnormal } \\
\text { spermatozoa }\end{array}$ \\
\hline Alkaline phosphatase/ml & $r$ & $\begin{array}{r}0 \cdot 04 \\
11 \cdot 47\end{array}$ & $\begin{array}{l}0 \cdot 16^{*} \\
0 \cdot 62\end{array}$ & $\begin{array}{l}0.06 \\
0 \cdot 78\end{array}$ & $\begin{array}{l}0.09 \\
0.37\end{array}$ & $\begin{array}{l}-0 \cdot 17^{*} \\
-0 \cdot 87\end{array}$ \\
\hline Acid phosphatase/ml & $\begin{array}{l}r \\
b\end{array}$ & $\begin{array}{l}-0 \cdot 24 * * \\
-22 \cdot 05\end{array}$ & $\begin{array}{l}0.21^{*} \\
0.25\end{array}$ & $\begin{array}{l}0 \cdot 30^{* *} \\
1.04\end{array}$ & $\begin{array}{l}0.13 \\
0.13\end{array}$ & $\begin{array}{l}-0.22 * * \\
-0.31\end{array}$ \\
\hline Alkaline/acid phosphatase (ratio) & $\begin{array}{l}r \\
b\end{array}$ & $\begin{array}{l}0 \cdot 16^{*} \\
4 \cdot 75\end{array}$ & $\begin{array}{l}-0 \cdot 28 * * \\
-0 \cdot 10\end{array}$ & $\begin{array}{l}-0 \cdot 24 * * \\
-0 \cdot 28\end{array}$ & $\begin{array}{l}-0.19^{*} \\
-0.07\end{array}$ & $\begin{array}{l}0 \cdot 24 * * \\
0 \cdot 12\end{array}$ \\
\hline $\begin{array}{l}\text { Alkaline phosphatase } / 500 \times 10^{6} \\
\text { cells }\end{array}$ & $\begin{array}{l}r \\
b\end{array}$ & $\begin{array}{r}0.15 \\
93.03\end{array}$ & $\begin{array}{l}-0 \cdot 26 * * \\
-2 \cdot 01\end{array}$ & $\begin{array}{l}-0 \cdot 27 * * \\
-6 \cdot 30\end{array}$ & $\begin{array}{l}-0.25 * * \\
-1.72\end{array}$ & $\begin{array}{l}0 \cdot 26^{* *} \\
2 \cdot 52\end{array}$ \\
\hline Acid phosphatase $/ 500 \times 10^{6}$ cells & 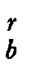 & $\begin{array}{r}0.07 \\
38 \cdot 39\end{array}$ & $\begin{array}{l}0.06 \\
0.45\end{array}$ & $\begin{array}{l}0.01 \\
0.22\end{array}$ & $\begin{array}{l}0.04 \\
0.27\end{array}$ & $\begin{array}{l}-0.07 \\
-0.62\end{array}$ \\
\hline $\begin{array}{l}\text { Alkaline/acid phosphatase } / 500 \times 10^{6} \\
\text { cells (ratio) }\end{array}$ & b & $\begin{array}{l}0.04 \\
5 \cdot 50\end{array}$ & $\begin{array}{l}-0 \cdot 30^{* *} \\
-0 \cdot 42\end{array}$ & $\begin{array}{l}-0.21 * * \\
-0.91\end{array}$ & $\begin{array}{l}-0 \cdot 23^{* *} \\
-0.29\end{array}$ & $\begin{array}{l}0 \cdot 28^{* *} \\
0 \cdot 49\end{array}$ \\
\hline
\end{tabular}

$r$, Simple correlation coefficient; $b$, simple regression coefficient.

$* P<0.05 ; * * P<0.01$.

centration of spermatozoa, significant negative correlations were obtained with the percentage of motile spermatozoa, concentration of spermatozoa, and the percentage of live spermatozoa, and a positive correlation with the percentage of morphologically abnormal spermatozoa.

\section{DISCUSSION}

Cytochemical studies by Bern (1949) and Rollinson (1954) have shown that alkaline phosphatase and acid phosphatase in mammalian semen are derived primarily from the secretions of the seminal vesicles and prostate gland. In the cock and turkey tom, the relatively high acid phosphatase activity of seminal plasma is derived mainly from the secretions of the vasa efferentia and vasa deferentia (Bell \& Lake, 1962). Roussel \& Stallcup (unpublished data) have demonstrated histochemically that alkaline phosphatase is secreted by the testis, caput epididymidis, corpus epididymidis and cauda epididymidis of Holstein-Friesian bulls: acid phosphatase was not present in the testis, but slight amounts observed in the caput epididymidis with increasingly larger 
amounts in the corpus epididymidis and the cauda epididymidis. Bern (1949) demonstrated cytochemically that alkaline phosphatase is present in the testis, epididymis and vas deferens of the rabbit. Haq \& Mullen (1949) found some biochemical evidence suggestive of the production of acid phosphatase by the testis and possibly by the epididymis, and they also found that bulls producing semen with low concentrations of spermatozoa also showed lowered seminal acid phosphatase activity. This is in agreement with the present observation of a positive correlation between acid phosphatase activity in seminal plasma and the concentration of spermatozoa.

Roussel \& Stallcup (1965) found that alkaline phosphatase and acid phosphatase activities in blood serum of Holstein-Friesian bulls, ranging from 1 to 95 weeks of age, were $2 \cdot 36 \pm 0.67$ and $0.29 \pm 0.18$ Sigma units $/ \mathrm{ml}$, respectively. It was further shown that alkaline phosphatase in blood serum is negatively correlated $(P<0.05)$ with age of bulls. It is unlikely, therefore, that the large amoun ts of alkaline phosphatase and acid phosphatase found in semen originate from blood, since the blood levels are very low. The functions of phosphatase in seminal plasma have been discussed by Rollinson (1954) and Mann (1964).

The alkaline phosphatase activity of semen is four times greater in the seminal plasma than in the spermatozoa. This was also essentially true for the acid phosphatase activities which are considerably lower. Bell \& Lake (1962), however, reported that alkaline phosphatase activity in whole semen was only slightly higher than acid phosphatase.

In the present study, the phosphatase activities in seminal plasma provided more correlations with other semen characteristics than phosphatase activities found in spermatozoa free of seminal plasma. The alkaline phosphatase activity of seminal plasma adjusted for cell concentration and the ratio of alkaline phosphatase/acid phosphatase activities in seminal plasma adjusted for cell concentration appear to provide the best indices of semen quality as judged by the percentage of motile spermatozoa, the percentage of live spermatozoa and the percentage of morphologically abnormal spermatozoa. Perhaps the metabolic activity of spermatozoa is influenced by the presence of phosphatase in seminal plasma.

\section{ACKNOWLEDGMENTS}

The authors express their appreciation to Mrs Donna Martin and Mrs Ella Nora Griffon for their assistance in carrying out this investigation, which was supported in part by Public Health Service Research Grant GM 10654-02 from the National Institutes of Health and by a grant from the National Associat ion of Animal Breeders, and is published with the approval of the Arkansa s Agricultural Experiment Station.

\section{REFERENCES}

BsLL, D. J . \& LAKE, P. E. (1962) A comparison of phosphomonoesterase activities in the seminal plasma of $\mathrm{t}$ he domestic cock, turkey tom, boar, bull, buck rabbit and of man. $\mathcal{J}$. Reprod. Fert. 3, 363 .

BERv, H. A. (1949) The distribution of alkaline phosphatase in the genital tract of the male mammals. A.ta t. Rec. 104, 361.

Evsberg, H., Anderson, E., Sury, B. \& Raft, J. (1947) The possibility of determining androgen prod uction by measuring the acid phosphatase in semen: Investigations in cryptorchid patients. J. En docr. 5, 42. 
HaQ, I. \& Mullen, J. E. C. (1949) Phosphomonoesterase in bull semen. Vet. Rec. 61, 145.

HeRMAN, H. A. \& MADDEN, F. W. (1963) The artificial insemination of dairy and beef cattle: $A$ handbook and laboratory manual. Lucas Brothers, Columbia, Missouri.

KING, E. J. \& Delory, G. E. (1945) Plasma phosphatase in the diagnosis of malignancy. Biochem. $\mathcal{F}$. 39 , iv.

LundQuisT, F. (1964) Function of prostatic phosphatase. Nature, Lond. 158, 710.

MANN, $T$. (1945) Studies on the metabolism of semen. 1. General aspects, occurrence and distribution of cytochrome, certain enzymes and coenzymes. Biochem. $\mathbf{7}$. 39, 451.

MANN, T. (1964) Biochemistry of semen and of the male reproductive tract. Methuen, London.

Reid, J. T., Ward, G. M. \& Salsbury, R. L. (1948) Acid and alkaline phosphatase levels in consecutive semen ejaculates from bulls. Am. F. Physiol. 153, 235.

Rollinson, D. H. L. (1954) A study of the distribution of acid and alkaline phosphatase in the genital tract of the Zebu bull (Bos indicus). F. agric. Sci. 45, 173.

Roussel, J. D. \& Stallcup, O. T. (1965) Influence of age on transaminase and phosphatase in male Holstein blood serum. 7. Dairy Sci. 48, 841.

Sigma Chemical Company (1963) The colorimetric determination of acid and alkaline phosphatase. Sigma Tech. Bull. 104, St Louis, Missouri.

Snedecor, G. W. (1956) Statistical methods, 5th edn. The Iowa State College Press, Ames, Iowa.

WILLETT, E. L. \& BuckNER, P. J. (1951) The determination of numbers of spermatozoa in bull semen by measurement of light transmission. F. Anim. Sci. 10, 219. 